\title{
Field performance of Pinus radiata D. Don produced in nursery with different types of containers
}

\author{
U. ORTEGA ${ }^{1, *}$, J. MAJADA ${ }^{2}$, A. MENA-PETITE ${ }^{1}$, J. SANCHEZ- \\ ZABALA $^{1}$, N. RODRIGUEZ-ITURRIZAR ${ }^{1}$, K. TXARTERINA ${ }^{3}$, \\ J. AZPITARTE ${ }^{4}$ and M. DUÑABEITIA ${ }^{1}$ \\ ${ }^{1}$ Departamento de Biología vegetal y Ecología. Facultad de Ciencias. Universidad del País Vasco/ \\ EHU. Apdo.- 644, 48080 Bilbao, Spain.; ${ }^{2}$ Forestry Section. Grado. SERIDA, Estación Experimental \\ "La Mata" apdo. 13, 33820 Asturias, Spain.; ${ }^{3}$ Basalan S.A. Diputación Foral de Bizkaia. Avda. \\ Madariaga 1-1 ${ }^{a}$ Plta. Dpto. 9, 48014 Bilbao, Spain.; ${ }^{4}$ Confederación de Forestalistas del País Vasco. \\ Barrio Gumuzio s/n, 48960 Galdakao, Spain.; *Address for Correspondence: Lab. Fisiología Vegetal., \\ Dpto. Biología Vegetal y Ecología., Facultad de Ciencias., UPV/EHU, Apdo.- 644, 48080 Bilbao, \\ Spain.(E-mail: gvborlau@lg.ehu.es; Fax: +34-4-4648500)
}

Received 22 October 2003; accepted in revised form 8 December 2004

Key words: Root architecture, Root deformations, Toppling, Seedling, Plantation establishment, Stock types

\begin{abstract}
We have studied the development in nurseries of containerized Pinus radiata produced with different container systems in order to choose the most suitable system for producing wellbalanced plants with an optimal root system. At the end of the production period, significant differences were found in morphological responses among the seedlings to the various container characteristics. Seedlings grown in containers that permitted lateral air puning presented less growth and lower biomass production. However, root deformations were more frequent and severe in plants produced in closed-wall containers. Field performance was likewise mainly affected by container type and plant growth rate, as faster grown plants showed more problems of stability than plants with a balanced root and stem development.
\end{abstract}

\section{Introduction}

Pinus radiata $\mathrm{D}$. Don occupies the $42 \%$ of the total forest area of the Basque Country (Northern Spain). It is the most important commercial tree species because it grows quickly, responds well to intensive management treatment aimed at producing high quality logs, and provides suitable timber for a wide range of end uses. Moreover, it is the only species for which there is a relatively advanced tree-breeding programme. The production of genetically improved seeds of radiata pine is increasing considerably, and silviculturists tend to reforest with containerized seedlings in order to benefit from the recent advances in research.

Containerized seedlings have a better survival rate, are easier to plant, have more immediate growth response benefits, and are cheaper to produce and plant than bareroot seedlings (Landis et al. 1990). As a result, many nurseries have changed from bareroot to containerized plant production and the demand for container radiata pine planting stock continues to increase every year. 
However, in recent years, the performance of containerized seedlings has presented serious problems of stability within the first five years after planting, with the appearance of deformed root systems apparently leading to loss of shoot growth, tree decline and mortality (Ortega et al. 2001). Early instability causing toppling of seedlings (Burdett et al. 1986), might be aggravated at wet sites or if seedlings are subjected to wind events accompanied by high-intensity or prolonged rainfall (Watson and Tombleson 2002). Toppling, resulting in stem deformities, is known to have a major impact on the future development of trees (Mason 1985; Sundström and Keane 1999). The economic significance of this problem is difficult to predict, but it would be expected that lumber recovery and value would be reduced (Burdett et al. 1986).

Several factors might contribute to toppling, e.g. inappropriate nursery conditions (Mason 1985), genetic factors (Coutts et al. 1999), planting methods (Long 1991; Mason et al. 1996) or the use of seedlings with distorted root systems (Burdett et al. 1986; Halter et al. 1993). Tree survival and growth after outplanting are directly related to the ability of the root system to rapidly produce new roots and grow out into the surrounding soil Schultz and Thompson 1997). In container-grown seedlings, root growth is restricted and problems of root bound plugs appear after planting (Landis et al. 1990). Therefore, container manufacturers continue to offer new features to control spiralling and produce well distributed, fibrous root systems. A new concept, which has been successfully developed in recent years, offers containers with vertical and/or horizontal slits in the walls to stimulate lateral air pruning, which prevents root spiralling and reduces the risk of early instability.

In this study two new container types were evaluated along with two conventional ones. Thus, four types of containers with different volumes, forms and materials were tested for their effect on morphology of Pinus radiata in the nursery. Field performance of the seedlings after outplanting was determined.

\section{Materials and methods}

The trial was independently established on August 1999 in three nurseries of the Basque Country. Radiata pine seeds (Pinus radiata D. Don, provenance NZ GF-13) were sown over a mixture of light and black peat (70/30 v/v) in four container types (Table 1 and Figure 1).

Seedlings were grown in a glasshouse for two months and were subsequently moved to an open greenhouse. The containers were set on frames above the ground to allow root air-pruning. Seedlings were maintained under regular irrigation. Fertilisation was applied by adding slow release ${ }^{\circledR}$ Plantacote plus (14-8-15 NPK $+2 \mathrm{MgO}$ ) (Aglukon, Valencia, Spain) to the substrate at $3 \mathrm{~g}$ $\mathrm{L}^{-1}$.

A total of 400 plants per treatment were grown in each nursery for a total of 8 months, when 25 plants per treatment were randomly harvested from the three nurseries. Shoot height, root collar diameter (RCD) and root and shoot dry weights $\left(80^{\circ} \mathrm{C}, 48 \mathrm{~h}\right)$ were determined at this point. 

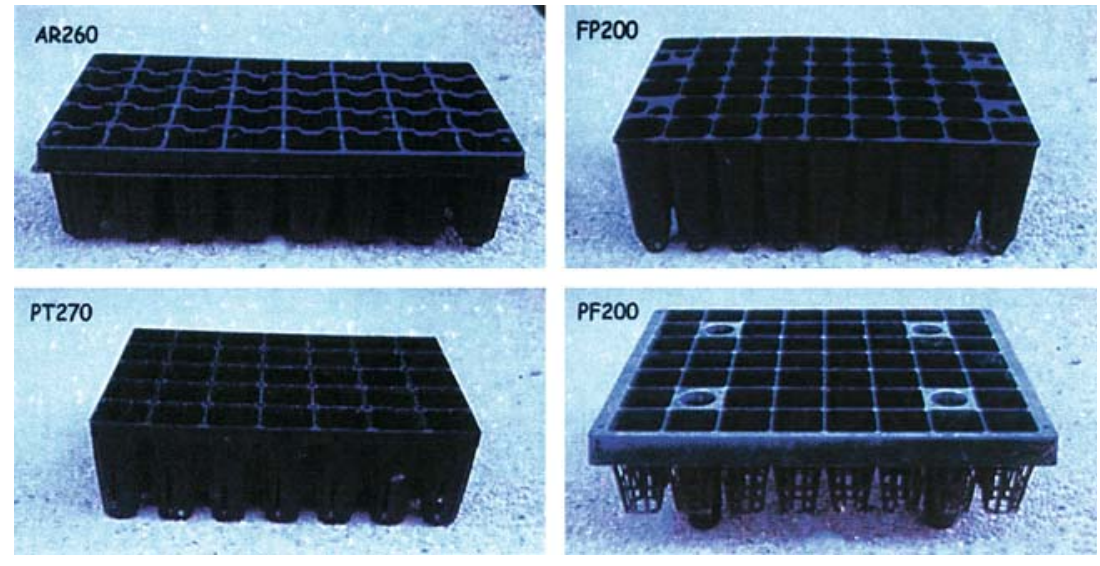

Figure 1. The four types of containers tested in the study.

Table 1. Characteristics of the containers tested.

\begin{tabular}{|c|c|c|c|c|c|c|c|}
\hline Tray & Material & $\begin{array}{l}\text { Cavity } \\
\text { number }\end{array}$ & Shape & Walls & $\begin{array}{l}\text { Volume } \\
\left(\mathrm{cm}^{3}\right)\end{array}$ & $\begin{array}{l}\text { Top size } \\
(\mathrm{mm})\end{array}$ & $\begin{array}{l}\text { Height } \\
(\mathrm{mm})\end{array}$ \\
\hline AR260 & $\begin{array}{l}\text { thermoformed } \\
\text { plastic }\end{array}$ & 40 & flexible prism & smooth & 260 & $64 \times 57$ & 150 \\
\hline FP200 & polyethylene & 50 & rigid prism & smooth & 200 & $46 \times 48$ & 150 \\
\hline PT270 & polyethylene & 35 & rigid prism & vertically grooved & 270 & $56 \times 59$ & 130 \\
\hline PF200 & polyethylene & 52 & rigid prism & grilled & 200 & $52 \times 52$ & 100 \\
\hline
\end{tabular}

In order to characterize root architecture, root deformation and related parameters were measured: the number of laterally deflected (more than 1 / 4 turn around taproot) and spiralling (more than $1 / 2$ turn around taproot) roots, the presence of packed roots (entwined and/or welded roots), taproot position (centred or off-centred taproot) and presence of an L-shaped taproot $(1 \mathrm{~cm}$ or more of the taproot pointed horizontally). Likewise, in order to study root distribution along the plug, root systems were subsampled into equal thirds of vertical extent (upper, middle and lower root systems) to measure the number and length of second and third order lateral roots.

To test plant field performance, a total of 4000 seedlings were outplanted in May 2000 in three trial sites located in Abellaneda (X 486601.98, Y 4787444.91, elevation $450 \mathrm{~m}$; Basque Country, North of Spain). Site properties and physico-chemical characteristics are summarised in Table 2. The sites differ in aspect, previous vegetation and soil preparation, soil $\mathrm{pH}$ (with values ranging from extremely to strongly acid), and nutrient status (especially in regard to soil $\mathrm{P}$ and $\mathrm{K}$ ). There is no significant air pollution at these sites and the soil characteristics appeared to present no restriction to root system development. 
Table 2. Soil $\mathrm{pH}$ and nutrient status, aspect, previous vegetation and soil preparation of the three sites in the outplanting trial.

\begin{tabular}{|c|c|c|c|c|c|c|}
\hline & $\mathrm{pH}$ & $\begin{array}{l}\text { Kjeldahl N } \\
(\%)\end{array}$ & $\begin{array}{l}\text { Olsen } \\
\text { P (ppm) }\end{array}$ & $\begin{array}{l}\mathrm{K} \\
(\mathrm{ppm})\end{array}$ & $\begin{array}{l}\text { Org. Mat. } \\
(\%)\end{array}$ & $\begin{array}{l}\text { Textural class } \\
\text { (USDA) }\end{array}$ \\
\hline Site 1 & 5 & 0.16 & 3 & 51 & 2.8 & Silty clay loam \\
\hline Site 2 & 4.5 & 0.13 & 4 & 52 & 2.7 & Silt loam \\
\hline \multirow[t]{2}{*}{ Site 3} & 5.1 & 0.19 & 3 & 46 & 5.8 & Silt loam \\
\hline & Aspect & Soil preparation & Slope & Previous vegetation & & \\
\hline Site 1 & $\mathrm{~N}$ & ripping & $8 \%$ & Pinus radiata & & \\
\hline Site 2 & E-SE & ripping & $22 \%$ & P. radiata $+C$. sativa & & \\
\hline Site 3 & E-SE & No ripping & $26 \%$ & Pinus radiata & & \\
\hline
\end{tabular}

The outplanting trial was a full factorial experiment, testing the four container types in a randomised complete block design planting at $2 \times 2.5 \mathrm{~m}$ tree spacing, adjusting the size of the plots ( 25 plants per plot and 13 replicates per site) to the conditions of each area, and using the local techniques of handplanting. In this assay, a minimum of 25 plots per treatment were evaluated. During the first 3 years of field growth, data on survival, plant height and stem diameter at $25 \mathrm{~cm}$ above the ground were measured. The leaning angle of the stem from the vertical was calculated and three categories were defined; trees leaning less than $15^{\circ}$ were classed as straight (Mason 1985), trees inclined between $15^{\circ}$ and $30^{\circ}$ were classed as moderately toppled, and trees inclined more than $30^{\circ}$ were classed as severely toppled.

In the second year after outplanting, 3 plants showing loss of verticality were extracted from each plot, digging a $0.5 \mathrm{~m}$ radius trench around the stem, in order to study root development and deformity persistence two years after outplanting. Root architecture was characterized by measuring taproot diameter at $15 \mathrm{~cm}$ from root collar, maximum rooting depth and number and radial distribution of first order lateral roots ( $>2 \mathrm{~mm}$ diameter). Root deformities were likewise assessed, recording the number of cases showing basal sweep, spiralling roots and knotty roots forming a mould with the shape of the container.

Analysis of variance was performed following a factorial model using the General Linear Models (GLM) procedure in ® SPSS Inc., Vs 10.0.6, 1999. Fisher's protected LSD test was used to test differences between the treatments if they were significantly ( $\mathrm{p} \leq 0.05)$ different in the main model of ANOVA. Only significant results $(\mathrm{p} \leq 0.05)$ are presented in the text. Regression and correlation analyses were also performed.

\section{Results}

At the end of the nursery stage, seedlings showed differences among treatments (Table 3). Seedlings grown in trays with higher volume per cavity (AR260 and 
Table 3. Mean shoot and root growth and biomass values, and root deformation related parameters (\% of plants) of the plants at the end of the nursery phase. Significant differences are indicated by different letters $(\mathrm{p} \leq 0.05)$ according to LSD tests.

\begin{tabular}{llllll}
\hline \multirow{2}{*}{ Tray type } & Height $(\mathrm{cm})$ & \multirow{2}{*}{ RCD $(\mathrm{mm})$} & \multicolumn{2}{l}{ Dry weight $(\mathrm{g})$} & \multirow{2}{*}{ Root surface $\left(\mathrm{cm}^{2}\right)$} \\
\cline { 4 - 5 } & & & \multicolumn{2}{l}{ Shoot } & Root \\
\hline AR260 & $25.1 \pm 2.6 \mathrm{a}$ & $3.7 \pm 0.11 \mathrm{a}$ & $2.77 \pm 0.21 \mathrm{a}$ & $0.69 \pm 0.05 \mathrm{a}$ & $48.2 \pm 1.8 \mathrm{a}$ \\
FP200 & $21.6 \pm 2.7 \mathrm{~b}$ & $3.5 \pm 0.10 \mathrm{a}$ & $2.56 \pm 0.23 \mathrm{a}$ & $0.64 \pm 0.03 \mathrm{a}$ & $42.9 \pm 2.8 \mathrm{a}$ \\
PT270 & $26.4 \pm 2.2 \mathrm{a}$ & $3.5 \pm 0.09 \mathrm{a}$ & $2.66 \pm 0.17 \mathrm{a}$ & $0.66 \pm 0.04 \mathrm{a}$ & $45.4 \pm 2.6 \mathrm{a}$ \\
PF200 & $19.1 \pm 3.5 \mathrm{~b}$ & $3.3 \pm 0.08 \mathrm{a}$ & $2.52 \pm 0.13 \mathrm{a}$ & $0.41 \pm 0.02 \mathrm{~b}$ & $19.5 \pm 0.9 \mathrm{~b}$ \\
& Off-centred & L-shaped & Packed-up & Spiralling & Upward growth \\
& taproot $(\%)$ & taproot $(\%)$ & plug $(\%)$ & roots $(\%)$ & of roots $(\%)$ \\
AR260 & 24.2 & 27.3 & 63.6 & 51.5 & 33.3 \\
FP200 & 28.1 & 28.1 & 84.3 & 68.8 & 43.7 \\
PT270 & 7.1 & 26.2 & 33.3 & 14.3 & 35.7 \\
PF200 & 10.7 & 0 & 0 & 10.7 & 28.5 \\
\hline
\end{tabular}

PT270) showed significantly $(\mathrm{P}<0.05)$ higher height values than seedlings grown in smaller containers (FP200 and PF200). In the case of RCD, only AR260 showed significantly higher values. In general, seedling biomass was higher in the case of larger containers, though differences were not significant. Only seedlings grown in PF200 containers showed significantly lower root dry weights, attributable to root air-pruning.

Lateral root distribution, number and length presented differences among container types (Figure 2). Total secondary root number did not vary with container type, but PF200 had the largest secondary root number in the plug bottom and the smallest in the upper part of the plug. Likewise, PF200 had significantly shorter secondary roots but similar secondary root lengths along the three parts of the plug, whereas in the other containers the longest secondary roots were found in the upper part of the plug. $200 \mathrm{~cm}^{3}$ containers produced significantly fewer tertiary roots, and in all cases the number of tertiary roots decreased from the upper to the lower part of the plug. Tertiary root length was also significantly affected by container type, as PT270 produced the longest roots, the majority being located in the upper and middle parts of the plug, whereas PF200 produced the shortest roots.

Likewise, container type had a marked effect on root deformities (Table 3). The grille-shaped wall design (PF200) container was the only one in which no L-shaped taproot was found, whereas in the remaining treatments around $25 \%$ of plants presented this deformity. No packed-up plugs were found in PF200 and only $33 \%$ of plants grown in PT270 presented this deformity. In contrast, seedlings grown in AR260 and FP200 showed high percentages of packed-up plugs and more than $50 \%$ of plants presented spiralling roots, whereas less than $14 \%$ of plants grown in PT270 and PF200 presented this deformity.

After field establishment, no differences in survival were recorded during the first two years (data not shown). In all cases, survival percentages were higher 


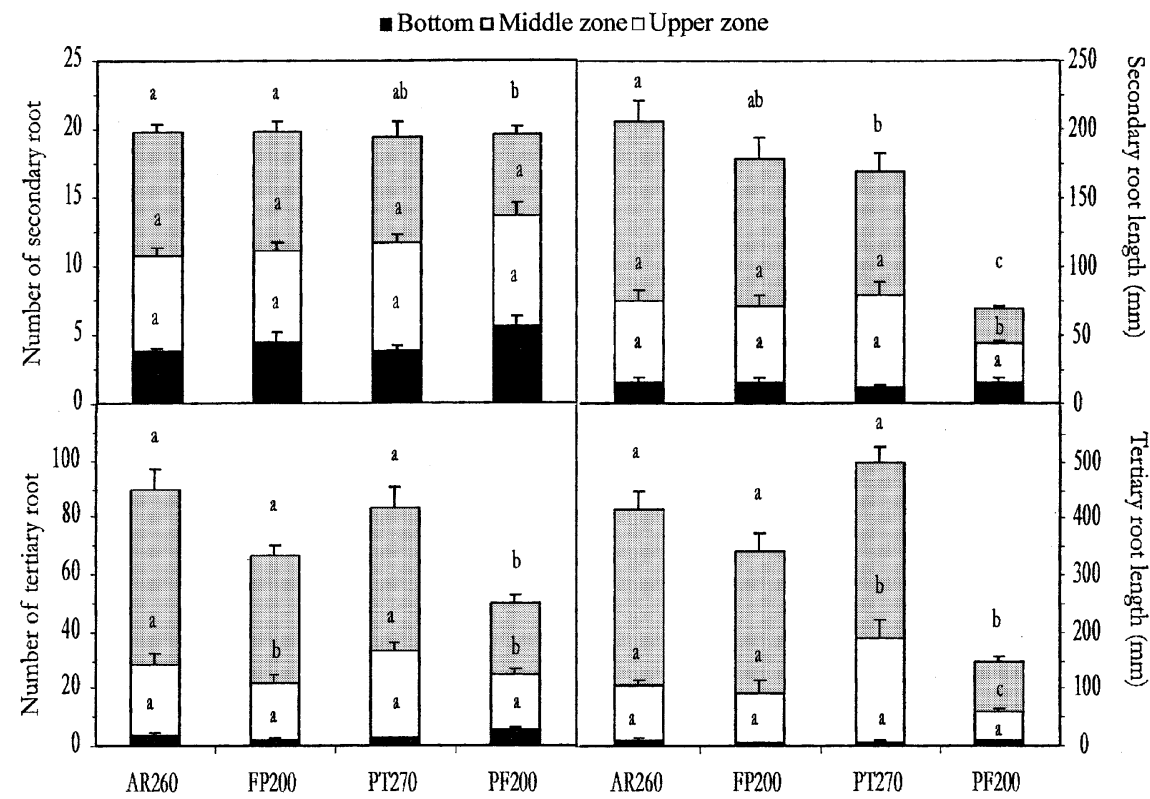

Figure 2. Number and length of secondary and tertiary roots, separating the root system into equal thirds of vertical extent (bottom, middle and upper zones), at the end of the nursery stage. Significant differences between container types within a given zone are indicated by different letters $(\mathrm{p} \leq 0.05)$ according to LSD tests.

than $95 \%$ and failures were mainly caused by animals (mares and roe deer). Field growth was mainly affected by planting site, since higher height and diameter values were achieved at Site 2, followed in turn by Site 1 and then by site 3 (Figure 3). With respect to container type, seedlings grown in PF200 showed the lowest height values in the three outplanting sites during the first three years of field performance.

A similar pattern was observed in the case of tree-lean, since mean leaning angle values in Site 3 were significantly higher than at Sites 2 or 1. Correlation between mean plant height and leaning angles for each container considering 6 plots from the three plantation sites showed high correlation coefficients (Figure 4). As regards containers, the mean value for AR260 was above $15^{\circ}$ from the vertical, considered by Mason (1985) as the lean at which a tree has toppled. Seedlings grown in PF200 toppled least in the three sites and the highest incidence of toppling was found in closed-wall containers, particularly during year 2002 (Table 4). However, a general tree straightness recovery was recorded on the third year after outplanting.

After plant extraction, no significant differences were found in root architecture with regards to plantation site (data not shown), although significant differences did appear with respect to container type (Table 5). When radial distribution of first order lateral roots was studied, seedlings grown in PF200 


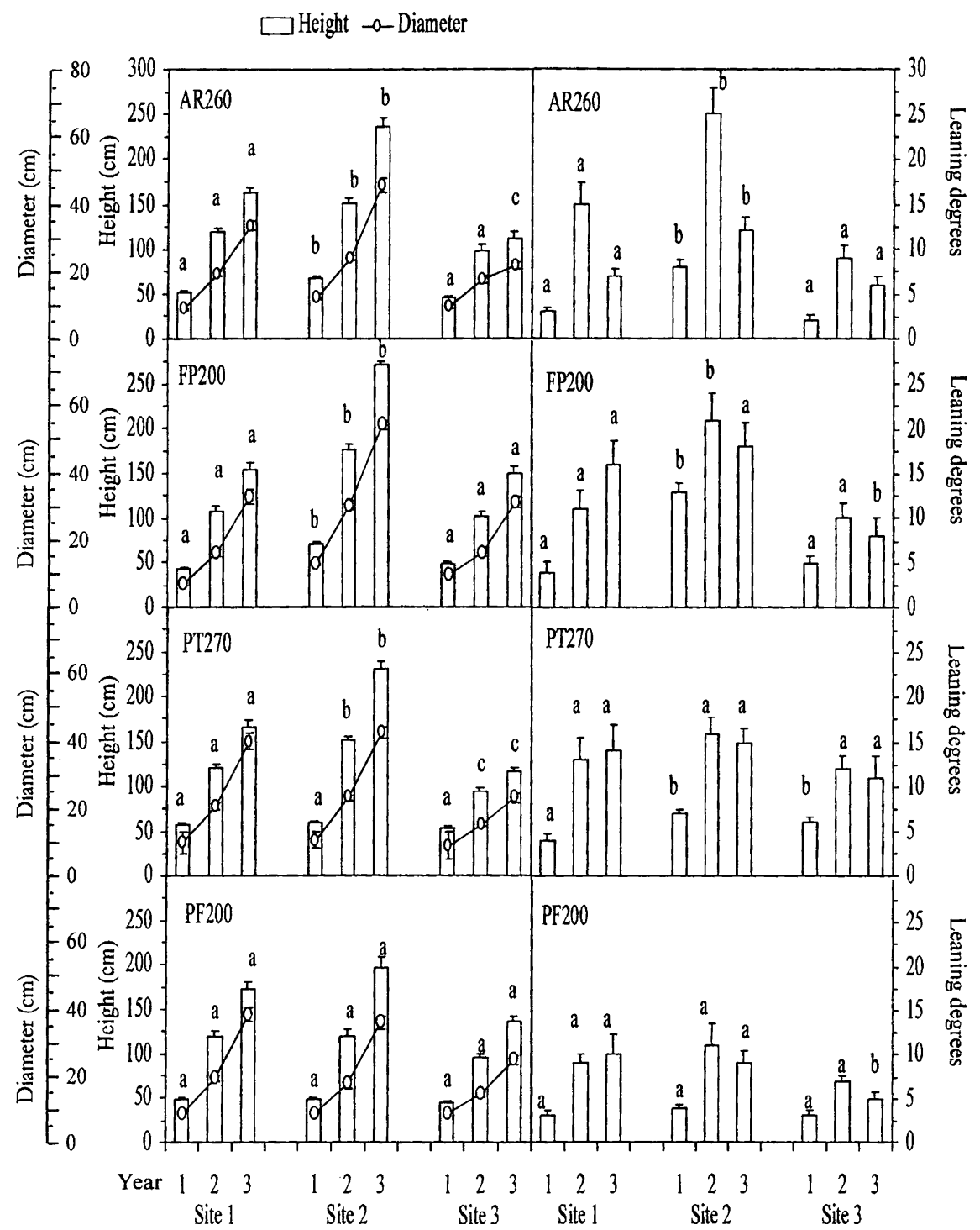

Figure 3. Field growth (height and diameter) and leaning degrees of the plants along the three years after planting at the three trial sites. Significant differences between sites within a given year are indicated by different letters ( $\mathrm{p} \leq 0.05$ ) according to LSD tests.

presented on average the highest root system symetry, whereas in the rest of the containers, between $1 / 3$ and $1 / 2$ of the circumference around the taproot lacked first order lateral roots. Similarly, with the exception of PF200, all the extracted plants showed spiralling roots and more than $70 \%$ presented L-shaped taproot and knotty roots. 


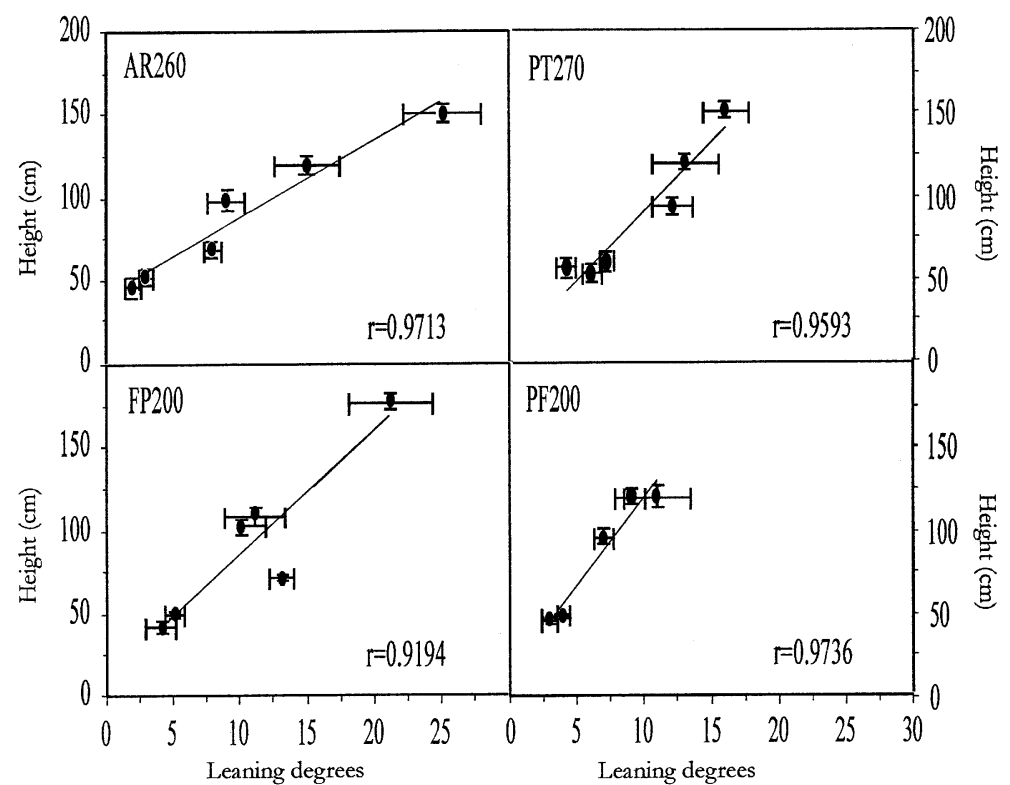

Figure 4. Correlation between height and leaning angle (mean values of 6 plots regardless planting site) of the plants two years after planting.

\section{Discussion}

At the end of the nursery stage, plant growth results show differences in both height and biomass among container types. A clear relationship is observed between container volume and plant biomass, as described by Lamhamedi et al. (1998). In the closed walls container (AR260), a large availability of soil volume favours plant development and decreases the incidence of root deformation inherent in this production system. Likewise, for the same cell volume, plants grown in PF200 (opened walls) show worse growth and biomass results than those grown in FP200 (closed walls). This indicates that a large wallaperture and a small volume affects plant development. Therefore, the management of these types of containers in the nursery requires special attention, owing to the greater exposure of both the substrate and plant to the environmental conditions of the nursery.

Due to the slots in the container sidewalls, PF200 stock's growing media dryed up faster during production compared to stock produced in the three types of hardwall containers. Because of the impossibility of applying extra water to a small number of PF200 seedlings growing operationally among a large amount of hardwall stock, the PF200 seedlings presented worse growth and biomass. In spite of the major differences in shoot size, most of the physiological and growth tests did not reveal any differences among seedlings grown in the four types of containers. The only difference was in the total 


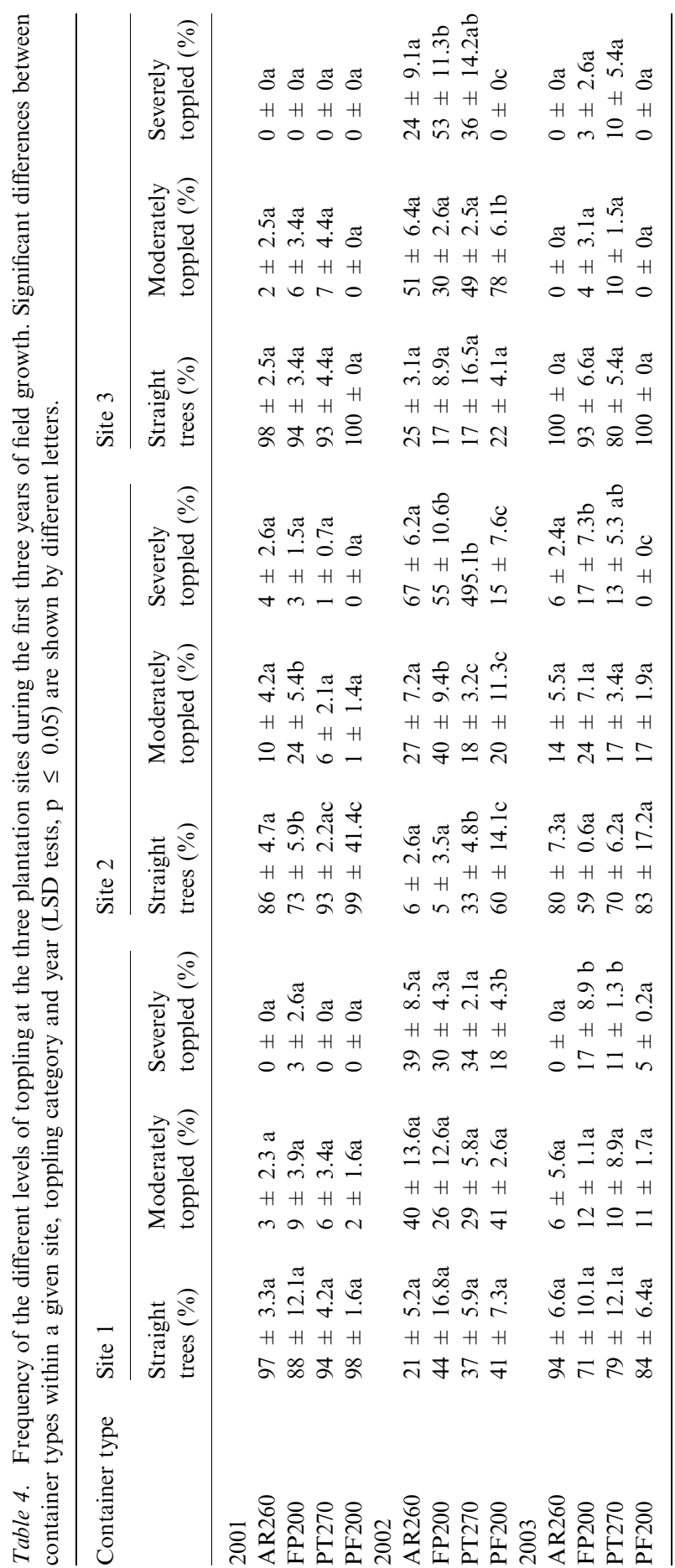


Table 5. Main root depth and root system symetry mean values regardless plantation site, and root deformations ( $\%$ of plants) found in the plants extracted after two years of field growth. Significant differences between container types are indicated by different letters $(\mathrm{p} \leq 0.05)$ according to LSD tests.

\begin{tabular}{lllllr}
\hline $\begin{array}{l}\text { Container } \\
\text { type }\end{array}$ & $\begin{array}{l}\text { Root depth } \\
\text { (cm) }\end{array}$ & $\begin{array}{l}\text { Degrees without } \\
\text { anchorage roots }\end{array}$ & $\begin{array}{l}\text { L-shaped } \\
\text { taproot }\end{array}$ & $\begin{array}{l}\text { Percentage of plants } \\
\text { with sprialling roots }\end{array}$ & Knotty roots \\
\hline AR260 & $27.7 \pm 1.9 \mathrm{a}$ & $138 \pm 12.4 \mathrm{ab}$ & 83 & 100 & 100 \\
FP200 & $26.6 \pm 2.2 \mathrm{a}$ & $154 \pm 14.3 \mathrm{a}$ & 100 & 100 & 80 \\
PT270 & $27.8 \pm 4.5 \mathrm{a}$ & $147 \pm 19.7 \mathrm{a}$ & 71 & 100 & 35 \\
PF200 & $20.8 \pm 0.8 \mathrm{a}$ & $83 \pm 19.4 \mathrm{~b}$ & 30 & 66 & 3 \\
\hline
\end{tabular}

number of secondary roots produced in the middle and bottom of the plug due to a bigger aeration of the growing media and to lateral root air pruning, being significantly higher $(\mathrm{P}=0.0001)$ for $\mathrm{PF} 200$ seedlings than for seedlings in the other three treatments.

Root deformations were clearly less pronounced in the grilled or slit-wall containers than in their closed-wall counterparts. Both closed-wall containers (AR260 and FP200) showed a higher percentage of off-centre pivot, packed-up plugs or spiralling roots than open-wall containers (PT270 and PF200), as seedlings grown in grilled-wall containers (PF200) did not develop any kind of root deformation. The development of deformed root systems increases with time as seedlings are grown in containers (Barnett and Brissette 1986; Balisky et al. 1995), and they may even appear before the root density in a walled container system has increased enough to facilitate normal extraction, handling and transportation (Balisky et al. 1995).

Root system structure varies with container type. In general, containers with vertical ribs on the inside prevented root spiralling. These containers result in a root structure characterized by a high number of vertically oriented roots, and roots develop along the walls of the container moulding to the shape of the container. Several studies have indicated that such ribs reduce spiralling and improve tree stability (e.g. Lindström and Håkansson 1995). However, other studies have shown that these ribs afford only a limited improvement in the root structure (e.g. Lindström 1994). Spiralling is not observed in the container with a greater soil volume and longitudinally opened walls, or in the grilledwall containers, in which root architecture is similar to a fishbone (Figure 5). Root growth in these systems is controlled mechanically or by air pruning. Unlike growth in hard-wall containers, where roots are directed toward the bottom, root growth in slit-wall containers can occur laterally through the slots, possibly forming a more "natural" root system.

Seedlings grown in the grille-shaped containers produced the least root biomass and least root surface, due to lateral root air-pruning rather than to container volume. However, this container type is the most advantageous one with respect to root system quality. Barnett and Brisette (1986) showed that container volume is less critical than seedling density in the development of 


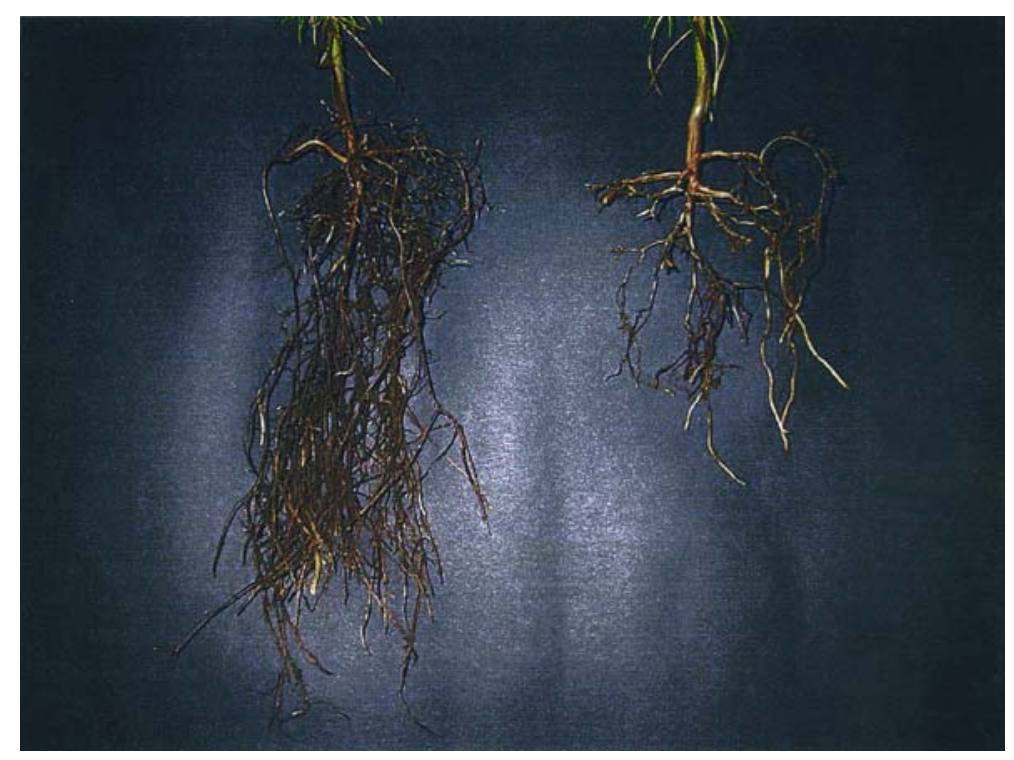

Figure 5. Root systems of seedlings at the end of the nursery stage of FP200 (left) and PF200 (right) stock, showing differences in root system structure.

container plants. We can say that container type is also a limiting factor in root development because it determines root architecture, as shown by secondary and tertiary root number and total length analyses. Accordingly, the seedlings grown in the PF200 containers produced a higher proportion of roots in the bottom two-thirds of the plug.

With regard to seedling stability performance after field outplanting, root morphology is also primarily influenced by site conditions (McMinn 1978; Bedford et al. 1996), and so it is difficult to determine the influence of initial root system shape on anchorage (Coutts 1983). Our results show that seedlings grown in grille-shaped containers gave the best results, ranging from $94 \%$ to $90 \%$ on sites without tree stability problems. These good results might be due to the fact that this system is to some extent a hybrid between bareroot plant production and container production. It has the advantages of the bareroot system, since root conformation and allometric relationships with the shoot would be similar to those in a direct-sown seedling. Likewise, not having the physical limitations of closed walls, root systems are developed with better root symmetry. Studies by AFOCEL in France on instability problems in young Pinus pinaster Ait. plantations (Auberlinger 1982; Cremiere 1994) concluded that the best root system quality was represented by plants with the fewer roots and the simplest root structure, i.e. similar to a fishbone. The negative effects on seedling growth of increasing root density within the confines of the container cavity, even before adequate root growth has occurred to bind the soil plug together, have been demonstrated (Salonius et al. 2000; Balisky et al. 1995). 
Opened-wall containers produced a well-balanced root system, as secondary root number and length presented a similar distribution along the plug as a consequence of lateral root air pruning. In the case of containers with closed walls, lateral roots reach the cavity wall and are deflected downward until they reach the cavity bottom. These are air pruned at the drainage hole, resulting in larger secondary roots at the top of the plug. After outplanting, these deflected lateral roots resume growth from the bottom of the plug, often forming a "pivot-point" on which the root plug and seedling top can move, resulting in a toppled tree (Burdett et al. 1986). Moreover, other authors report high correlations between increasing root density in walled container systems, and decreasing field root growth (Salonius et al. 2000).

Considerable emphasis has been placed by previous studies on evenly balanced lateral root distribution and strong, well-developed taproots (AimersHalliday et al. 1999; Lindström and Rune 1999) or on the wind-induced increased radial growth of near-stem lateral roots and the subsequent increase in rigidity of this area (Watson and Tombleson 2002) as the major contributors to juvenile tree wind stability. It is generally assumed that naturally regenerated and direct-sown trees are less prone to topple than other plant types, because they have a more evenly balanced lateral root distribution and a stronger, welldeveloped taproot system than planted trees (Aimers-Halliday et al. 1999; Lindström and Rune 1999). Studies carried out on toppled and non-toppled trees aimed at identifying the root system components that are important for the wind-stability of young planted trees (Mason 1985; Gautam et al. 1999) support the proposition that lateral root distribution and well-developed taproot systems are important to juvenile tree stability.

In our case, when considering radial distribution of first order lateral roots, the container with grilled walls (PF200) had the smallest sectors without theese roots $\left(83^{\circ}\right)$. The average sector in the remaining containers where first order lateral roots were absent was $>138^{\circ}$, higher than the critical value of $120^{\circ}$ regarded by Nielsen (1997) as critical for future stability. Differences in root system form could arise fiom differences in root direction or from differential growth and survival of roots. In practice, both the direction of growth and differential development contribute to the final form (Coutts 1989). Radiata pine first order lateral roots (henceforth lateral roots), which originate directly from taproots or the root core, are the main framework for supporting lower order coarse roots that anchor trees (Mason 1985; Coutts 1987; Gautam et al. 1999). In addition, lateral roots are the main framework for the development of fine roots, the amount of which is related to tree growth (Nambiar 1984; Theodorou and Bowen 1993; Gautam et al. 2003a). Thus, Gautam et al. (2003b) hypothesize that tree planting material possessing a higher number of lateral roots will be more competitive with understorey species and enhance aboveground growth.

Nevertheless, although root deformations produced by containers seem to condition plant development to some extent, these are not the main factor producing the tree instability observed in the three experimental plantations. In 
fact, plants grown in open-wall containers also showed excessive inclination and root deformations. There are reasons, such as the high correlation between seedling height and tree leaning, to believe that the higher frequency of basal sweep found in this study was related to seedling size and planting technique rather than to root variables conditioned by container type.

Toppling in our study may be due to an imbalance between a large shoot and a small root system, partially caused by the continuous drive to improve growth through genetic improvement and provenance selection (Sundström and Keane 1999). A vigorous fast-growing shoot has to be supported and balanced by a vigorous root system (Nielsen 1992). However, it is generally accepted that radiata pine is prone to topple when fast growth occurs during the first years after planting. Hence, fast early 'top' growth (and toppling) may occur with both container stock and bareroot stock.

Although the effect of container type on growth was the same regardless of planting environment (i.e. no significant planting site X. container type interaction), the planting environment had a major effect on seedling growth. Similar results were found by Melanie et al. (2002) when making comparisons between copper-treated styrofoam containers and hardwall containers with side slits. The high incidence of toppling at Site 2 may be linked to the higher growth rate of the seedlings at this site. In fact, the vegetation prior to plantation at this site was a mixed forest of radiata pine and abundant chestnuts, and soil preparation consisted of ripping. This provided a more fertile soil than in the other two sites and, as suggested by Watson and Tombleson (2002) for plantations on ex-farm sites, such soils are thought to encourage out of balance crown growth on fertile soil at the expense of the below-ground biomass. In these circumstances, a large sailing area, a small root system, and a strong wind can result in toppling. In other cases, toppling has been reduced by ripping which increased taproot development (Mason 1985). Greater soil nitrification of pasture versus clearcuts sites (Carlyle et al. 1989) or rapid rates of juvenile growth on fertile sites (Turvey et al. 1993) have been associated with stem sinuosity of radiata pine in Australia. A tree with a large crown and small root system may topple more readily when the overturning moment caused by wind exceeds the maximum resistive moment provided by a small root mass (Moore and Somerville 1998).

Several studies on radiata pine in Australia have identified a higher incidence and severity of stem sinuosity at sites that received shallow ripping treatments (Mason 1985; Balneaves and DeLa Mare 1989). These studies concluded that stem sinuosity was linked to bent taproots resulting from planting into soil conditions that restricted root growth (stem sinuosity increased with decreasing depth of root penetration and with decreasing straightness of the taproot). Negative effects of wrenching had diminished by the third year after field establishment. The stand became more wind-resistant with age. As trees grow older, early stem deformations will be compensated by radial growth and the tree will straighten. The near-stem lateral roots of young trees thicken to become supporting structural roots (Watson and Tobleson 2002). A secondary 
thickening will occur, whereby the size and shape of the root cross-section will be altered in response to wind-induced root movement (Nicoll et al. 1995; Nicoll and Ray 1996; Stokes et al. 1997).

However, just because a planted pine seedling has a bent taproot, this does not mean it will performance worse than seedlings that originate from direct seeding (South 1999). In one study, 32 percent of loblolly pines (Pinus taeda L.) originating from seed had bent taproots (Harrington et al. 1989). Bends in the taproot can be "natural" as well as "man-made".

Besides the rapid shoot growth during the first years after field outplanting, our results indicate that both the extended nursery rearing technique, that is commonly practised to produce larger containerized conifer seedlings, and the planting method were the factors that most strongly affected plant performance. In all assayed container types, plants presented bent taproots after two years of field development, probably caused by poor planting technique.

Future problems with unstable radiata pine plantations may be reduced by using good nursery practice. Likewise, the control of the fertilisation during the nursery production phase will allow optimum plant growth rate and adequate planting stock quality, thus avoiding extra months of extended nursery rearing. Moreover, the use of containers that allow lateral root growth through slits in the sidewall, together with the adoption of a correctly applied planting technique (seedlings planted with minimal distortion) may result in improved juvenile stability of Pinus radiata.

\section{Acknowledgements}

We thank the Departamento de Agricultura del Gobierno Vasco for financial support. We are very grateful to Luis Mari Arteach (Basalan S.A., Diputacion Foral de Bizkaia) for giving every facility for plant production. Our special thanks to Gerardo Llaguno for managing and taking care of the plants in the nursery during the study. Thanks also to Eduardo Aguirre (Servicio de Montes, Departamento de Agricultura, Diputacion Foral de Bizkaia) for advice and support in this work. Funding assistance does not imply endorsement of any statements of information contained herein.

\section{References}

Aimers-Halliday J., Holden G., Klomp B. and Menzies M. 1999. Soften the blow - planted age cutting on topple-prone sites. What's New in Forest research, No. 248. New Zeal. For. Res. Inst. Ltd.

Auberlinger V. 1982. De l'instabilité du Pin maritime. Afocel Annales, pp.139-176.

Balisky A.C., Salonius P., Walli C. and Brinkman D. 1995. Seedling roots and forest floor: misplaced and neglected aspects of British Columbia's reforestation effort. For. Chron. 71: 59-65.

Balneaves J.M. and DeLaMare P.J. 1989. Root patterns of Pinus radiata on five ripping treatments in a Canterbury forest. New Zeal. J. For. Sci. 19: 29-40. 
Barnett J.P. and Brissette J.C. 1986. Producing southern pine seedlings in containers. U.S.D.A Forest Serv., South. Forest Exp. Sta. U.S.D.A Forest Serv, New Orleans, La pp. 72, Gen. Tech. Rep. SO-59.

Bedford L., Martin P. and Scagel R. 1996. Bednesti Site: Testing the biological effectiveness of mechanical site preparation equipment (Preliminary results). Tour of Bednesti, September 24. BCMOF/CFS FRDA II, pp. 109.

Burdett A.N., Coates H., Eremko R. and Martin P.A.F. 1986. Toppling in British Columbia's lodgepole pine plantations: significance, cause and prevention. For. Chron. 62: 433-439.

Carlyle J.C., Turvey N.D., Hopmans P. and Downes G.M. 1989. Stem deformation in Pinus radiata associated with previous land use. Can. J. For. Res. 19: 96-105.

Coutts M.P. 1983. Root architecture and tree stability. Plant and Soil 71: 171-188.

Coutts M.P. 1987. Developmental process in tree root system. Can. J. For. Res. 17: 761-770.

Coutts M.P. 1989. Factors affecting the direction of growth of tree roots. Ann. Sci. For. 46: 277287.

Coutts M.P., Nielsen C.N. and Nicoll B.C. 1999. The development of symmetry, rigidity and anchorage in the structural root system of conifers. Plant and Soil 217: 1-15.

Cremiere L. 1994. Conteneurs: Quelles consequences pour le Pin maritime. Afocel Fiche Informations-Foret. $\mathrm{N}^{\circ} 477$.

Gautam M., Mead D.J., Frampton C. and Chang S.X. 1999. Coarse root system characteristics and toppling of clonal and seedlings trees of Pinus radiata on Canterbury Plains. New Zeal. J. For. Sci. 44: 15-18.

Gautam M.K., Chang S.X., Mead D.J., Clinton P.W. and Roberts E.H. 2003a. First order lateral root characteristics reflect the competitiveness of radiate pine genotypes in agroforestry systems. Australasia Forestry Conference, Queenstown, New Zealand April 2003: 1-10.

Gautam M.K., Mead D.J., Clinton P.W. and Chang S.X. 2003b. Biomass and morphology of Pinus radiata coarse root components in temperate silvopastoral systems. For. Ecol. Man. 177: 387397.

Halter M.R., Chanway C.P. and Harper G.J. 1993. Growth reduction and root deformation of containerised lodgepole pine saplings 11 years after planting. For. Ecol. Man. 56: 131-146.

Harrington C.A., Brissette J.C. and Carbon W.C. 1989. Root system structure in planted and seeded loblolly and shortleaf pine. For. Sci. 35: 469-480.

Lamhamedi M.S., Bernier P.Y., Hebert C. and Jobidon R. 1998. Physiological and growth responses of three sizes of containerized of Picea mariana seedlings outplanted with and without vegetation control. For. Ecol. Man. 110: 13-23.

Landis D., Tinus R.W., Mc Donald S.E. and Barnett J.P. 1990. Containers and growing media. Vol.2. The container tree nursery manual. Agriculture Handbook 674. US Department of Agriculture, Forest Service, Washington, DC, pp. 87.

Lindström A. 1994. Stability of young container pine stands. Canadian Silviculture Magazine 2: 16-20.

Lindström A. and Håkansson L. 1995. Going to the root of the evil. Canadian Silviculture Magazine 3: 14-17.

Lindström A. and Rune G. 1999. Root deformation in plantations of container-grown Scots pine trees: effects on root growth, tree stability and stem straightness. Plant and Soil 217: 29-37.

Long A.J. 1991. Proper planting improves performance. In: Duryea M.L. and Dougherty P.M. (eds.), Forest Regeneration Manual. Kluwer Academic Pub., Dordrecht, The Netherlands pp.303-320

Mason E.G. 1985. Causes of juvenile instability of Pinus radiata in New Zealand. New Zeal. J. For. Sci. 15: 236-28.

Mason E.G., Sputh D.B. and Weizhong Z. 1996. Performance of Pinus radiata in relation to seedling grade, weed control, and soil cultivation in the central North Island of New Zealand. New Zeal. J. For. Sci. 26: 173-183.

McMinn R.G. 1978. Root development of white spruce and lodgepole pine seedlings following outplanting. In: Van Eerden E. and Kinghorn J.M. (eds.), Proceedings of the Root Form of 
Planted Trees Symposium, May 16-19, 1978, Victoria B.C.. B.C. Min. For./CFS Joint Rep. No.8, pp. 186-190.

Melanie D.J., Kiiskila S. and Flanagan A. 2002. Field performance of pine stock types: Two-year results of a trial on interior lodgepole pine seedlings grown in Styroblocks ${ }^{\mathrm{TM}}$, Copperblocks ${ }^{\mathrm{TM}}$, or AirBlocks ${ }^{\mathrm{TM}}$. B. C. Journal of Ecosystems and Management 2(1): 1-12.

Moore J. and Somerville A. 1998. Assessing the risk of wind damage to plantation forests in New Zealand. New Zeal. For. 43: 25-29.

Nambiar S. 1984. Significance of first order lateral roots on the growth of young radiata pine under environmental stress. Aus. For. Res. 14: 187-199.

Nicoll B.C., Easton E.P., Milner A.D., Walker C. and Coutts M.P. 1995. Wind stability factors in tree selection; Distribution of biomass within root system of Sitka spruce clones. In: Coutts M.P. and Graace J. (eds), Wind and Trees. Cambridge University Press, Cambride, UK, pp. 276-292.

Nicoll B.C. and Ray D. 1996. Adaptative growth of the root systems in response to wind action and site conditions. Tree Physiol. 16: 891-898.

Nielsen C.N. 1992. Will traditional conifer tree breeding for enhanced stem production reduce wind stability? Silvae Genetica 41: 307-318.

Nielsen C.N. 1997. The calculation module for structural roots in the TREEARCH-database. Internal report, 8. The Arboretum, Royal Vet. Agric. Univ., Copenhagen.

Ortega U., Rodríguez N., González-Murua C., Majada J., Azpitarte I., Txarterina K. and Duñabeitia M. 2001. Estudio de la calidad de planta de Pinus radiata en envase. In: Montes para la sociedad del Nuevo Milenio. III Congreso Forestal Español Vol. III.. Junta de Andalucía. SE2499-2001. Consejería de Medio Ambiente.III pp.354-359.

Salonius P., Beaton K. and Roze B. 2000. Effects of cell size and spacing on root density and field performance of container-reared black spruce. Can. For. Servo.- Atl. For. Ctr. Inf. Rep. M-X208E, pp. 21.

Schultz R.C. and Thompson J.R. 1997. Effect of density control and undercutting on root morphology of $1+0$ bareroot hardwood seedlings: five-year field performance of root-graded stock in the central USA. New Forests 13: 301-314.

Soil Survey Staff. 1998. Keys to Soil Taxonomy, 8th ed. Natural Resources Conservation Service, United States Department of Agriculture, Washington, DC.

South D.B. 1999. Which loblolly pine seedling has a higher survival potential a deep planted J-root or a shallow planted I-root?' February ' Tenth Biennial Southern Silvicultural Research Conference, Shreveport, LA, pp. 16-18.

Stokes A., Nicoll B.C., Coutts M.P. and Fitter A.H. 1997. Responses of young Sitka spruce clones to mechanical perturbation and nutrition: effects on biomass allocation, root development and resistance to bending. Can. J. For. Res. 27: 1049-1057.

Sundström E. and Keane M. 1999. Root architecture, early development and basal sweep in containerized and bare-rooted Douglas fir (Pseudotsuga menziesii). Plant and Soil 217: 65-78.

Theodorou C. and Bowen G.D. 1993. Root morphology, growth, and uptake of phosphorous and nitrogen of Pinus radiata families in different soils. For. Ecol. Man. 56: 43-56.

Turvey N.D., Downes G.M., Hopmans P., Stark N., Tomkins B. and Rogers H. 1993. Stem deformation in fast grown Pinus radiata: an investigation of causes. For. Ecol. Man. 62: 189-209.

Watson A.J. and Tombleson J.D. 2002. Toppling in juvenile pines: A comparison of the root system characteristics of direct-sown seedlings, and bare-root seedlings and cuttings. Plant and Soil 239: 187-196. 